\section{New Bone Formation around Implants Inserted on Autologous and Xenografts Irradiated or not with IR Laser Light: A Histomorphometric Study in Rabbits}

Luiz Guilherme P. Soares ${ }^{1}$, Edival Barreto de Magalhães Júnior ${ }^{1}$, Cesar Augusto B. Magalhães ${ }^{2}$, Cimara Fortes Ferreira ${ }^{3}$, Aparecida Maria C. Marques ${ }^{1}$, Antônio Luiz B. Pinheiro ${ }^{1,4,5}$

Use of biomaterials and light on bone grafts has been widely reported. This work assessed the influence of low-level laser therapy (LLLT) on bone volume (BV) and bone implant contact (BIC) interface around implants inserted in blocks of bovine or autologous bone grafts (autografts), irradiated or not, in rabbit femurs. Twenty-four adult rabbits were divided in 8 groups: $A G$ : autograft; $X G$ : xenograft; $A G / L$ : autograft + laser; $X G / L$ : xenograft + laser; $A G / I$ : autograft + titanium (Ti) implant; $X G / I$ : xenograft + Ti implant; $A G / I / L$ : autograft + Ti implant + laser; and XG/I/L: xenograft + Ti implant + laser. The animals received the Ti implant after incorporation of the grafts. The laser parameters in the groups $A G / L$ and $X G / L$ were $\lambda=780 \mathrm{~nm}, 70 \mathrm{~mW}, C W, 21.5 \mathrm{~J} / \mathrm{cm}^{2}$, while in the groups $A G / \mathrm{I} / \mathrm{L}$ and $X G / \mathrm{l} / \mathrm{L}$ the following parameters were used: $\lambda=780 \mathrm{~nm}, 70 \mathrm{~mW}, 0.5 \mathrm{~cm}^{2}$ (spot), $4 \mathrm{~J} / \mathrm{cm}^{2}$ per point (4), $16 \mathrm{~J} / \mathrm{cm}^{2}$ per session, $48 \mathrm{~h}$ interval $x 12$ sessions, CW, contact mode. LLLT was repeated every other day during 2 weeks. To avoid systemic effect, only one limb of each rabbit was double grafted. All animals were sacrificed 9 weeks after implantation. Specimens were routinely stained and histomorphometry carried out. Comparison of non-irradiated and irradiated grafts $(A G / L$ versus $A G$ and $X G / L$ versus $X G)$ showed that irradiation increased significantly $B V$ on both grafts $(p=0.05, p=0.001)$. Comparison between irradiated and non-irradiated grafts $(A G / / / L$ versus $A G / I$ and $X G / I / L$ versus $X G / I)$ showed a significant $(p=0.02)$ increase of the BIC in autografts. The same was seen when xenografts were used, without significant difference. The results of this investigation suggest that the use of LLLT is effective for enhancing new bone formation with consequent increase of bone-implant interface in both autologous grafts and xenografts.
'Center of Biophotonics, Dental School, UFBA - Federal University of Bahia, Salvador, BA, Brazil ${ }^{2}$ UFSC - Federal University of Santa Catarina, Center for Education and Research in Dental Implants Itacorubi, Florianopolis, SC, Brazil ${ }^{3}$ Department of Periodontology, University of Tennessee School of Dentistry, Memphis, TN, USA ${ }^{4}$ Camilo Castelo Branco University, Núcleo do Parque Tecnológico de São José dos Campos, São José dos Campos, SP, Brazil ${ }^{5}$ National Institute of Optics and Photonics, Physics Institute of São Carlos, USP - University of São Paulo, São Carlos, SP, Brazil

Correspondence: Prof. Dr. Antônio Luiz Barbosa Pinheiro, Avenida Araújo Pinho, 62, Canela, 40110-150 Salvador, BA, Brasil. Tel: +55-713283-9010. e-mail: albp@ufba.br

Key Words: bone repair, low-level laser therapy.

\section{Introduction}

Bone losses are major problems in many medical and dental specialties and may occur due to several physiologic and pathologic conditions. Aging is a major cause of physiologic bone loss. Bone tissue has enormous regenerating capacity, and most of the time it is able to restore its usual architecture and mechanical properties. However, there are limits to this capacity, and complete recovery may not occur if there is deficient blood supply, mechanical instability or competition with highly proliferating tissues. The loss of bone fragments or the removal of necrotic or pathologic bone, or even some surgical procedures may create bone defects. These defects may be too large for spontaneous and physiologic repair (1).

Another cause of bone defects is the removal of a tooth. The lack of functional stimulation of the alveolar bone induces a continuous process of bone resorption, resulting in defects in bone volume, both vertically and horizontally, thus preventing rehabilitation with dental implants. The reestablishment of three-dimensional bone volume is mandatory to allow prosthetic rehabilitation with dental implants in their optimum space position (2).

Atrophic edentulous bone ridges require, prior the insertion of a dental implant, an increase of the bone volume that is mainly carried out by bone grafting procedures. The autologous bone graft (autograft), type is considered the gold standard for reconstruction techniques due to their osteogenic capacity (3). However, intraoral donor sites are of limited use for extensive reconstruction procedures (4). The mandible is a major source for bone grafts, but permanent numbness has been shown as a sequel after harvesting bone in areas close to the inferior alveolar nerve (5).

There are several methods to improve bone repair, and these include the use of grafts and lately the use of lowlevel laser therapy (LLLT). Nowadays, a major problem in dentistry is the bone repair process on defects caused by trauma, surgical procedures or pathologies. A wide range of biomaterials has been used aiming to improve the repair of these defects. Both autografts and xenografts provide good structure and stimulation of bone new bon formation, apart from the possibility of their combination with membranes in the guided bone regeneration technique (GBR) $(6,7)$. 
Bone grafts may be classified based both on morphological and immunological aspects. According to morphological criteria, they are classified as cancellous, cortical and cortico-spongeous. The latter is characterized by faster revascularization than the cortical one, showing thin trabeculae separated by large marrow spaces filled with hematopoietic cells, facilitating cell migration, but does not provide significant mechanical support (8).

In the classification of the sources used for recovery of bone loss there are those obtained from human bone tissue (autologous and allogeneic) and those of animal origin (xenograft). Among the synthetically produced (alloplastic) materials the most widely used are the hydroxyapatites (9).

Bovine bone grafts have shown to be a successful alternative to autografts. The use of this material eliminates the need of a second surgical site to harvest the donor tissue, thereby reducing morbidity of the procedure. The bovine bone is a filling material used since the 1990's, presenting significant literature support regarding its effectiveness as a bone regenerative material (1). These studies showed the biocompatibility of the xenograft. However, there is still a debate as to its rate of resorption and replacement with time. Animal studies have demonstrated a low resorption rate, with a high amount of particles present in the longterm, without full replacement by vital bone formation (10).

These materials have physical and biological properties compatible with the host tissue. Moreover, bone matrix was shown to deposit over it in large defects, showing its osteoconductive property. Severely atrophic maxillas require extensive bone reconstructions by onlay of bone blocks in order to re-establish the vertical and horizontal contour required for installation of tooth implants (11).

Despite the success of using biomaterials in bone repair process, several studies evaluated different types of treatment aimed to more effective results. For this reason, the use of laser energy associated with biomaterials has been applied in several scientific researches $(9,12)$.

Low-level laser therapy has been reported as an important resource to positively stimulate bone both in vivo and in vitro. These results indicate that photo-physical and photochemical properties of some wavelengths are primarily responsible for the tissue responses (1). The use of correct and appropriate parameters was shown to be effective for the promotion of a positive biomodulating effect on the healing bone (1).

The results of studies by our research group and by others indicate that bone irradiated mostly with infrared (IR) wavelengths shows increased osteoblastic proliferation, collagen deposition and bone new bon formation when compared with non-irradiated bone. The results of studies by this group indicate that an effective outcome of LLLT is observed when the treatment is carried out at early stages when high cell proliferation occurs. Vascular responses to LLLT were also suggested as one of the possible mechanism responsible for the positive clinical results observed following LLLT. It still remains uncertain if bone stimulation by laser light is a general effect or rather an isolate stimulation of osteoblasts is possible (1).

The literature has shown the use of LLLT as an adjuvant to enhance bone regeneration by its biostimulation effects. Initially, laser stimulates the cell redox mechanism leading to an increase in ATP synthesis and in a series of biochemical events responsible for cell proliferation and differentiation (1). The LLLT stimulus on the wounded bone site in experimental studies has a positive effect in the mesenchymal cells differentiation into osteoblasts, it increases matrix deposition in the early events of bone formation and is considered a key factor to accelerate bone regeneration (13-15). Moreover, laser therapy has been used to enhance bone quality and mechanical strength around implant interface (16-19).

Our research group has evaluated histologically the effect of LLLT $(\lambda=830 \mathrm{~nm}, 50 \mathrm{~mW}, C W)$ in the repair process of autologous bone grafts. The results demonstrated that in groups where laser was applied to the surgical cavity during surgery, bone remodeling activity was qualitatively and quantitatively more exuberant when compared with the other groups and that LLLT has a positive effect on bone repair process (20). In another study, the efficacy of $\operatorname{LLLT}\left(\lambda=790 \mathrm{~nm}, 50 \mathrm{~mW}, \mathrm{CW}, 10 \mathrm{~J} / \mathrm{cm}^{2}\right)$ was histologically investigated by light microscopy. It was found that in all treatment groups new bone formation was greater and qualitatively better than in the untreated subjects. Control specimens showed a less advanced repair after 40 days and they were characterized by presence of medullar tissue, small amount of bone trabeculae and some cortical repair. It was concluded that LLLT had a positive biomodulating effect on the healing of bone defects, and that this effect was more evident when LLLT was performed on the surgical bed intra-operatively, prior to the placement of the autologous bone graft (21).

The aim of this study was to assessed by a histomorphometric analysis the influence of laser phototherapy on bone formation around titanium (Ti) implants inserted in blocks of different types of bone grafts in rabbits, irradiated or not.

\section{Material and Methods}

The present study was approved by the Ethics in Animal Research Committee of the Dental School of the Federal University of Bahia (Protocol \#07/2008). Twenty-four adult female rabbits ( 7 months old) weighting 3 to $3.5 \mathrm{~kg}$ were used in this study. After intramuscular sedation (1) and general anesthesia (2), two surgical phases were carried 
out at two separate moments.

Initially, an autologous bone graft was removed from the iliac crest of each animal (Fig. 1A-C). The autograft had the same size of a xenograft (2) (Fig. 1D,E). Local hemostasis was controlled by intramuscular injection of local anesthetics (2). A 6-cm-wide incision was made in the femoral biceps until reaching the periosteum. A round bur was used for decortication of the receptor site (Fig. 1F). The animals were then divided into 4 groups: $A G$ : autograft; $X G$ : xenograft; $A G / L$ : autograft + laser; XG/L: xenograft + laser; $A G / I$ : autograft + Ti implant; XG/I: xenograft + Ti implant; AG/I/L: autograft + Ti implant + laser; and XG/I/L: xenograft + Ti implant + laser. In the irradiated groups, immediately after the surgical procedure the receptor surgical site was irradiated by a diode laser (2) with the following parameters: $\lambda=780 \mathrm{~nm}, 70 \mathrm{~mW}, \mathrm{CW}, 21.5 \mathrm{~J} / \mathrm{cm}^{2}$ (Fig. 1G). Each graft was fixed to the epiphysis by a screw (Fig. 1H,I) and sutured (2). Postoperatively, prophylactic intramuscular administration of $0.8 \mathrm{mg} / \mathrm{kg}$ of enrofloxacin (2) and $0.8 \mathrm{mg} / \mathrm{kg}$ of flunixin (3) was used once a day for 3 days.

The following irradiations were carried out every other day for 2 weeks on the irradiated groups. The irradiation protocol (2) has been previously reported $(1,20,21)$. To avoid systemic effect of laser light, only one limb of each rabbit was grafted; the other limb had no treatment. Half of the animals were killed by an overdose of general anesthetics 8 weeks after surgery for assessment of the graft incorporation.

In order to verify the efficacy of the previous protocol carried out in phase 1 , the remaining animals were then divided into other 4 groups: $A G / I$ : autograft + Ti implant; XG/I: xenograft + Ti implant; $A G / I / L$ : autograft + Ti implant
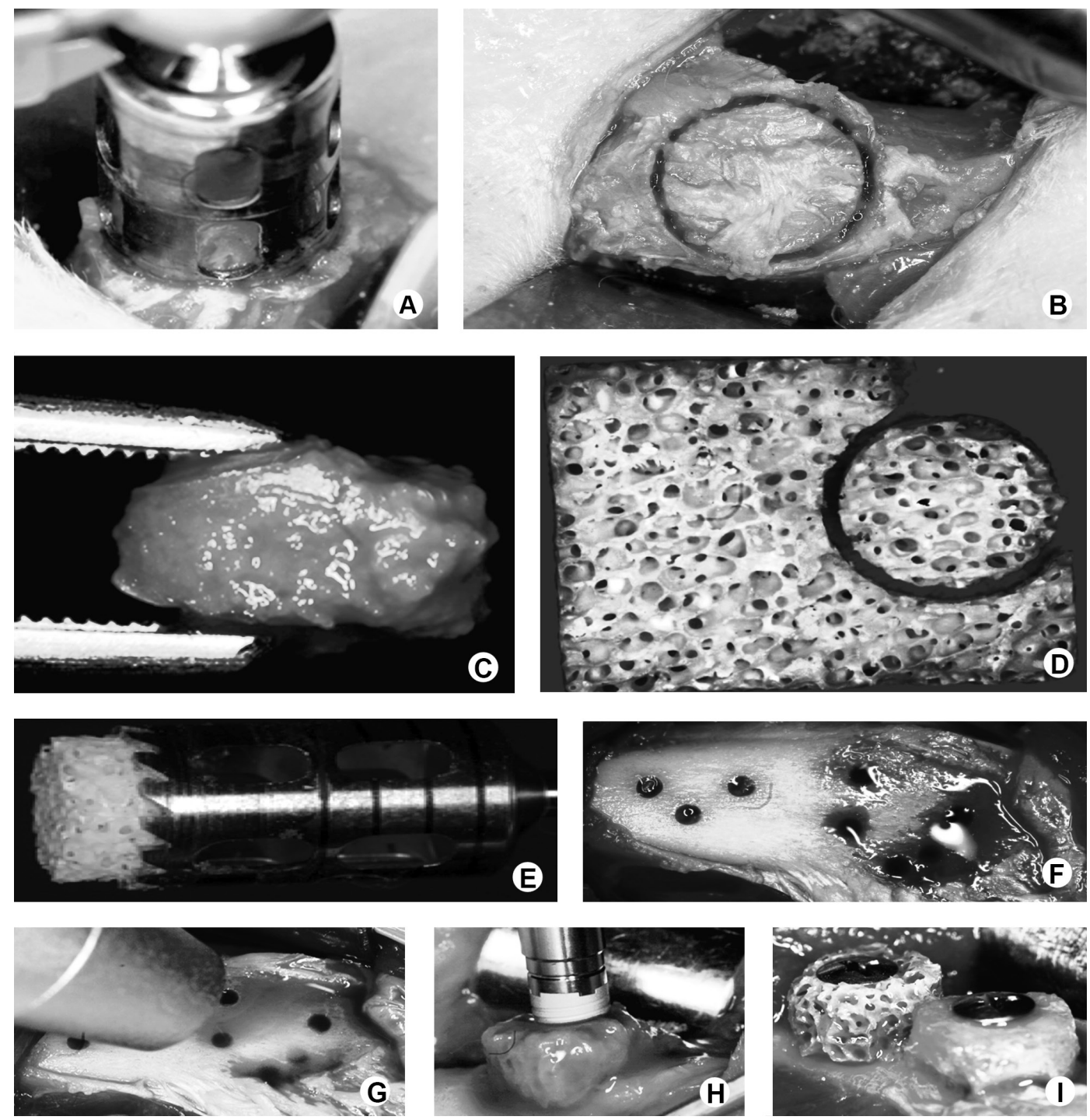

Figure 1. A: The autologous bone graft was prepared with a round trephine. B: The donor site was delimited. C: The autograft was removed. D: The same procedure was carried out on the block of the xenograft. E: The xenograft had the same size of the autograft. F: A round bur was used for decortication of the receptor site. G: The receptor surgical site was irradiated by a diode laser. H,l: Each graft was fixed to the epiphysis by a screw. 
+ laser; and XG/I/L: xenograft + Ti implant + laser. A 3.5x7 $\mathrm{mm}$ dental implant was inserted in each of the previously grafted sites (Fig. 2A,B). In the irradiated groups, LLLT $\left(\lambda=780 \mathrm{~nm}, 70 \mathrm{~mW}, 0.5 \mathrm{~cm}^{2}\right.$ (spot), $4 \mathrm{~J} / \mathrm{cm}^{2}$ per point (4), $16 \mathrm{~J} / \mathrm{cm}^{2}$ per session, $48 \mathrm{~h}$ interval $\times 12$ sessions, $\mathrm{CW}$, contact mode) was used as previously described (9). The animals were euthanized as previously described 30 days after insertion of the implants.

Specimens were obtained (Fig. 2C) and fixed in 4\% formalin, routinely processed and embedded in glycometil methacrylate (2). Subsequently, the sections were grounded to $70 \mu \mathrm{m}$ thickness. The sections were stained using toluidine blue and acid fuchsine. Photomicrographs (2) were taken from each slide and specific software (2) was used to carry out the morphometric analysis.

The following parameters were used for this analysis: Bone volume percentage (BV) (2), (percentage of the newly formed bone + remnants of the graft + medullar spaces and connective tissue above the graft-bed interface (Fig. 3A,B), was calculated for all groups, and the bone implant contact (BIC) interface (3), a measurement of perimeter of 3 threads of the implant (Fig. 3C) that correspond to the amount of bone in direct contact with the implant, was calculated for groups $A G / I / L$ and $X G / / / L$. Statistical analysis was carried out by ANOVA, two-sample t-test using a statistical software package (3) and significance level set to $5 \%$.

\section{Results}

The comparison between groups $X \mathrm{G}$ and $\mathrm{AG}$, as regards bone new bon formation, showed that non-irradiated grafts presented a mean of $43.1 \pm 4.7 \%$ and $10.7 \pm 2.1 \%$ for autografts and xenografts, respectively, with a significant difference $(p=0.0001)$. The same was observed when xenografts were used $(p=0.009)$. On irradiated subjects, the mean volume was $40.6 \pm 7.2 \%$ and on non-irradiated ones it was $10.7 \pm 2.1 \%$. The comparison between irradiated grafts $(X G / L$ and $A G / L)$ demonstrated higher percentage of new bon formation in the autograft group (48.7 \pm $14.8 \%)$ compared with the xenograft group ( $40.5 \pm 7.2 \%)$, without significant difference $(p>0.05)$. Comparison of non-irradiated and irradiated grafts $(A G / L$ versus $A G$ and $X \mathrm{G} / \mathrm{L}$ versus $\mathrm{XG}$ ) showed that irradiation increased bone new bon formation on both types of graft, with significant differences ( $p=0.05$ and $p=0.001$, respectively).

As regards the graft remnants, the autograft group showed smaller percentage of remnants $(15.71 \pm 6.5 \%)$ in comparison with the xenograft group (37.10 $\pm 5.7 \%)$, without significant difference $(p>0.05)$. Irradiation on both types of grafts did not change the pattern observed on non-irradiated ones. The percent of remnants of the xenograft $(15.7 \pm 11.7 \%)$ was higher than in the autograft $(13.17 \pm 5.2 \%)$, also without significant difference.

The percentage of connective tissue when using the
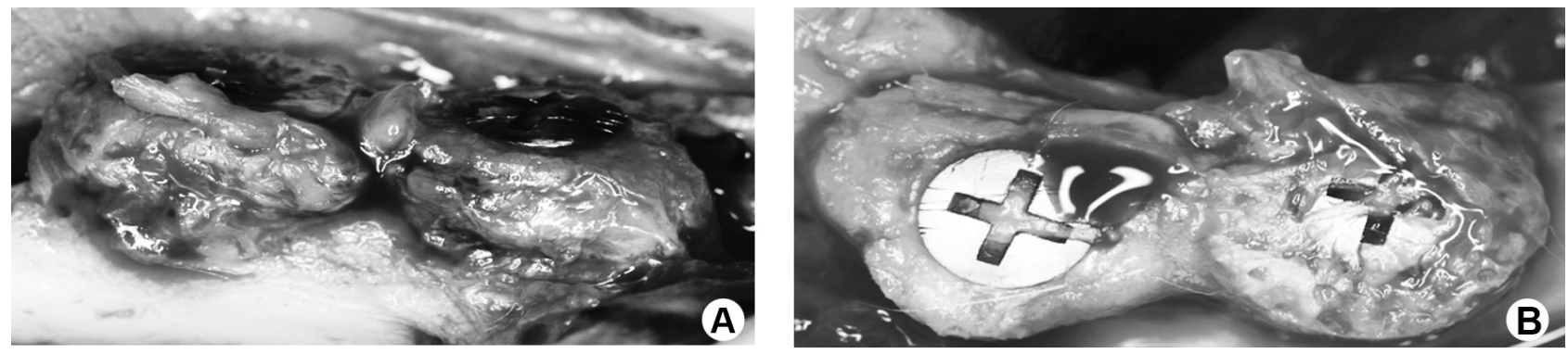

Figure 2. Aspect of the grafts at the time of sacrifice $(A, B)$.
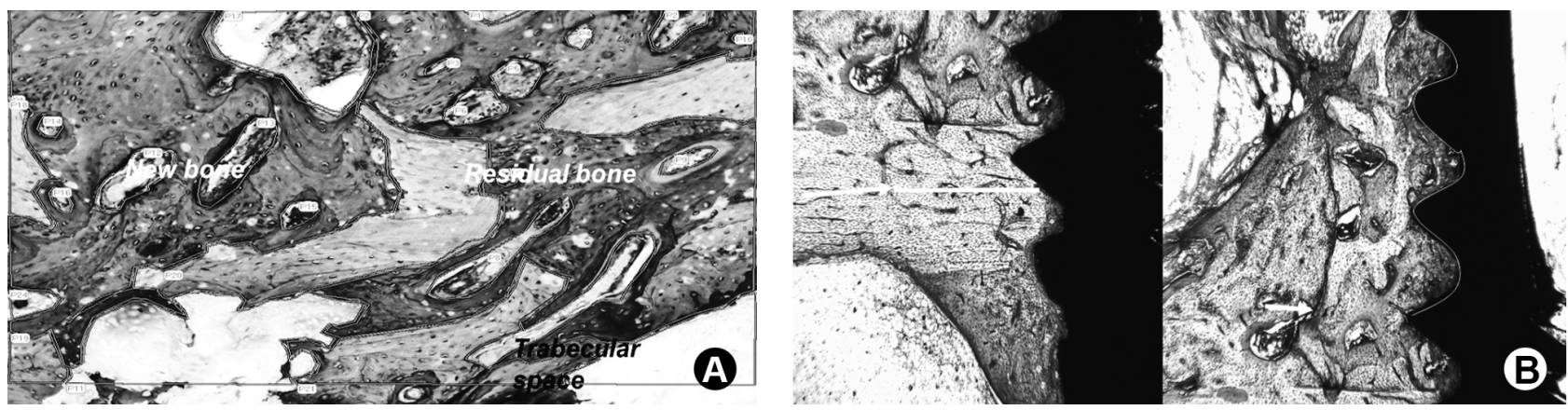

Figure 3. A,B: Bone volume percentage (BV) of the newly formed bone + remnants of the graft + medullar spaces and connective tissue above the graft-bed interface were delimited. C: Bone implant contact (BIC) interface, the perimeter of 3 threads of the implant that corresponded to the amount of bone in direct contact with the implant, was measured. 
different grafts was higher in subjects grafted with the xenograft $(52.2 \pm 7.7 \%)$ in comparison with the autograft $(41.6 \pm 7.2 \%)$, with a significant difference $(p=0.04)$. The irradiation of both types of grafts did not change the pattern, since higher percentage was seen when xenografts were used $(43.7 \pm 16 \%)$. In this case the difference was also significant $(\mathrm{p}=0.04)$.

The results of newly formed bone measurements, volume of graft remnants and amount of connective tissue obtained 9 weeks after graft implantation are summarized in Table 1. The results of BIC interface of the grafts submitted to the insertion of dental implants are summarized on Table 2.

Assessment of the interface implant-receptor bed of both grafts (Groups XG/I and $A G / I$ ) revealed higher percentage when xenografts were used $(58.9 \pm 8.6 \%)$ if compared with autologous bone grafting $(37 \pm 5.4)$, with a significant difference $(p=0.008)$. Irradiation of the graft (Groups XG/I/L and $A G / / / L$ ) resulted in higher percentage in subjects submitted to autologous bone grafting (70 \pm $13.6 \%)$ compared with those submitted to xenograft (65.3 \pm 9.7\%) without significant difference. Comparison between irradiated and non-irradiated grafts $(A G / I / L$ versus $A G / I$ and $X G / / / L$ versus $X G / I)$ showed a significant $(p=0.02)$ increase of the contact interface in cases where autografts were used ( $37 \pm 5.4 \%$ and $70 \pm 13.6 \%$ respectively). The same was seen when xenografts were used $(58.9 \pm 8.6 \%$ and $65.3 \pm$ $9.7 \%$, respectively) without significant difference $(p=0.03)$.

\section{Discussion}

Vertical bone augmentation is a complex reconstructive surgical procedure that may require onlay graft blocks for reestablishing the tridimensional bone volume prior to placement of tooth implants. According to the Swiss Society of Oral Implantology, all two-stage augmentation procedures are considered complex (11). Autogenous bone graft is considered the gold standard when bone atrophy is present, but it increases morbidity. Considering that specific surgical procedures are performed with block grafts, the bone formation and resorption rates for xenograft blocks are still unknown.

Table 1. Means (\%) and standard deviations of newly formed bone measurements, volume of graft remnants and amount of connective tissue 8 weeks after graft implantation

\begin{tabular}{lccc}
\hline $\begin{array}{l}\text { Group } \\
\text { ( } \mathrm{n}=6 \text { sites) }\end{array}$ & $\begin{array}{c}\text { Newly formed } \\
\text { bone }\end{array}$ & Graft remnants & $\begin{array}{c}\text { Connective } \\
\text { tissue }\end{array}$ \\
\hline $\mathrm{AG}$ & $43.1 \pm 4.7 \%$ & $15.71 \pm 6.5 \%$ & $41.6 \pm 7.2 \%$ \\
$\mathrm{XG}$ & $10.7 \pm 2.1 \%$ & $37.10 \pm 5.7 \%$ & $52.2 \pm 7.7 \%$ \\
$\mathrm{AG} / \mathrm{L}$ & $48.7 \pm 14.8 \%$ & $13.17 \pm 5.2 \%$ & $36.8 \pm 9.0 \%$ \\
$\mathrm{XG} / \mathrm{L}$ & $40.5 \pm 7.2 \%$ & $15.7 \pm 11.7 \%$ & $43.7 \pm 16 \%$ \\
\hline
\end{tabular}

This study compared histomorphometrically the bone tissue responses of autologous or xenografts, irradiated or not with laser light, in which dental implants were inserted and afterwards irradiated or not with IR laser light 9 weeks after grafting in rabbits.

The results of the present study suggest a higher amount of bone formation by laser stimulation. The length of the post-implantation time established for the present study was to ascertain complete graft healing and incorporation into the recipient site, in order to allow for titanium implant placement. In the present study, histomorphometrical analysis showed that LLLT associated with a prolonged (9 weeks) healing period resulted in statistically significant new bone formation. The positive effect of laser was noticed in the irradiated animals, as the percentage of autogenous group irradiated with laser was significantly higher when compared with the other groups. The advantage of autologous bone grafts is due to their osteogenic property $(20,21)$.

This study showed higher new bone formation in the irradiated autogenous group $(50.04 \pm 16.72 \%)$ compared with the non-irradiated groups $(42.72 \pm 4.93 \%)$. Moreover, the percentage of new bone formation was $40.56 \pm 7.16 \%$ against $10.69 \pm 2.11 \%$ for the laser irradiated xenograft group when compared with the non-irradiated group, respectively, which was statistically significant. Gerbi et al. (7) evaluated the influence of LLLT on bone remodeling of particulate bovine grafts implanted in rat femurs, and suggested that laser had a positive effect in increasing the amount of collagen fibers in the early stages of healing. As type I collagen is the main component of the bone matrix, it would play a key role in a higher degree of new bone formation in a later stage of healing.

Although the histological repair sequence of events in autografts is similar to xenografts, the lack of viable osteocytes in the xenografts makes them biologically inferior to the autologous ones. In the present study, laser irradiation showed positive stimulation on the xenograft, probably due to stimulation of the blood cells that flow from pristine bone near the graft. Another factor that might have increased the percentage of new bone formation could

Table 2. Means (\%) and standard deviations of the bone-implant contact (BIC) interface measurements

\begin{tabular}{lcc}
\hline Group & Time & Bone-implant contact interface \\
\hline $\mathrm{AG} / \mathrm{l}$ & & $37.0 \pm 5.4 \%$ \\
$\mathrm{XG} / \mathrm{l}$ & $58.9 \pm 8.6 \%$ \\
$\mathrm{AG} / \mathrm{l} / \mathrm{L}$ & 9 weeks & $70.0 \pm 13.6 \%$ \\
$\mathrm{XG} / \mathrm{l} / \mathrm{L}$ & $65.3 \pm 9.7 \%$ \\
\hline
\end{tabular}


be the laser parameters used in this study. Other studies $(7,12,16,23)$ have shown the improvement of bone quality by photobiostimulation, due to a significant positive effect in bone quality tissue and early implant loading.

Additional studies should be performed to validate the use of LLLT to enhance bone healing, using bone markers and a trabecular bone from a different animal model. Moreover, LLLT's potential to stimulate bone formation in xenografts should be analyzed in the presence of membrane barriers and growth factors. In addition, mechanical tests should be conducted with implants placed in xenograft blocks after healing period in order to test their physical properties.

The results of this investigation suggest that the use of LLLT is effective for enhancing new bone formation and consequent increase of bone-implant interface in both autologous grafts and xenografts.

\section{Resumo}

0 uso de biomateriais e luz em enxertos ósseos têm sido relatados. Esse trabalho avaliou a influência do laser baixa potência - LBP no volume ósseo (VO) e superfície de contato osso-implante (COI) ao redor de implantes dentários inseridos em blocos de enxerto bovino ou autólogos incorporados, irradiados ou não, em fêmures de coelho. Vinte e quatro coelhos adultos foram divididos em 8 grupos: EA: enxerto autólogo; EX: enxerto xenógeno; EA/L: enxerto autólogo + laser; EX/L: enxerto xenógeno + laser; EA/I: enxerto autólogo + implante; EX/l: enxerto xenógeno + implante; EA/I/L: enxerto autólogo + implante de titânio + laser; EX/I/L: enxerto xenógeno + implante de titânio + laser. Os animais receberam um implante de titânio após a incorporação dos enxertos. Os parâmetros de laser nos grupos $E A / L$ e $E X / L$ foram $\lambda=780 \mathrm{~nm}, 70 \mathrm{~mW}, \mathrm{CW}, 21,5 \mathrm{~J} / \mathrm{cm}^{2}$ ), enquanto que nos grupos $E A / I / L$ e $E X / / / L$ os seguintes parâmetros de laser foram utilizados: $\lambda=780 \mathrm{~nm}, 70 \mathrm{~mW}, 0,5 \mathrm{~cm}^{2}$ (spot), $4 \mathrm{~J} / \mathrm{cm}^{2}$ por ponto (4), $16 \mathrm{~J} / \mathrm{cm}^{2}$ por sessão, intervalo de $48 \mathrm{~h} \times 12$ sessões, $\mathrm{CW}$, modo contato. 0 LBP foi repetido a cada $48 \mathrm{~h}$ ( 2 semanas). Para evitar efeito sistêmico apenas um membro de cada coelho foi duplamente enxertado. Todos os animais foram sacrificados 9 semanas após o implante. Os espécimes foram corados rotineiramente e histomorfometria foi realizada. A comparação dos enxertos não-irradiados e irradiados ( $E A / L$ versus $E A$ e $E X / L$ versus EX) mostrou que a irradiação aumentou significantemente $(p=0,02) o$ V0 para ambos os tipos de enxertos $(p=0,05, p=0,001)$. A comparação dos enxertos não-irradiados e irradiados (EA/I/L versus EA/I e EX/I/L versus EX/I) mostrou um aumento significante $(p=0,02)$ do $\mathrm{COI}$ nos enxertos autólogos e xenógenos sem diferença estatística. Os resultados desta investigação sugerem que o uso de LBP é efetivo para aumentar a neoformação óssea com consequente aumento do $\mathrm{COI}$ em enxertos autólogos e xenógenos.

\section{Acknowledgments}

The authors acknowledge the Conselho Nacional de Desenvolvimento Científico e Tecnológico (CNPq) for providing financial support.

\section{References}

1. Pinheiro ALB, Gerbi MEMM. Photobioenerginnering of the bone repair process. Photomed Laser Surg 2006;24:169-178.

2. Chiapasco $M$, Casentini $P$, Zaniboni $M$. Bone augmentation procedures in implant dentistry. Int J Oral Maxillofac Implants 2009;24(suppl):237-259.

3. Jensen $\mathrm{S}$, Terheyden $\mathrm{H}$. Bone augmentation procedures in localized defects in the alveolar ridge: clinical results with different bone grafts and bone substitute materials. Int J Oral Maxillofac Implants 2009;24(suppl):218-236.

4. Weibull L, Widmark G, Ivanoff C, Rasmusson L. Morbidity after chin bone harvesting - A retrospective long term follow-up study. Clin Implant Dent Relat Research 2009;11:149-157.

5. Aghallo T, Moy, P. Which hard tissue augmentation techniques are most successful in furnishing bony support for implant placement? Int J Oral Maxillofac Implants 2009;24(suppl):49-70.

6. Pinheiro ALB, Limeira Jr FA, Gerbi MEMM, Ramalho LMP, Marzola C, Ponzi EAC, et al.. Effect of $830 \mathrm{~nm}$ laser light on the repair of bone defects grafted with inorganic bovine bone and decalcified cortical osseous membrane. J Clin Laser Med Surg 2003;21:383-388.

7. Gerbi MEMM, Pinheiro ALB, Marzola C, Limeira Jr FA, Ramalho LMP, Ponzi $E A C$, et al.. Assessment of bone repair associated with the use of organic bovine bone and membrane irradiated at $830 \mathrm{~nm}$. Photomed Laser Surg 2005;23:382-388.

8. Day SM, Ostrum RF, Chao EYS, Rubin CT, Aro HT, Einhorn TA. Bone injury, regeneration and repair. In: Orthopaedic basic science. Buckwalter JA, Einhorn TA, Simon SR (eds). Chicago:AA0; 2000;p 371-399.

9. Pinheiro ALB, Gerbi MEMM, Limeira Jr FA, Ponzi EAC, Marques AMC, Carvalho $\mathrm{CM}$. et al.. Bone repair following bone grafting hydroxyapatite guided bone regeneration and infra-red laser photobiomodulation: a histological study in a rodent model. Lasers Med Sci 2009;24:234-240.

10. Canullo L. Vertical ridge augmentation around implants using e-PTFE titanium reinforced membrane and deproteinized bovine bone mineral: A case report. Int J Periodontics Restorative Dent 2006;26:355-361.

11. Buser D, Martin W, Belser U. Optimizing esthetics for implant restorations in the anterior maxilla: Anatomic and surgical considerations. Int J Oral Maxillofac Implants 2004;19(suppl):43-61.

12. Pinheiro ALB, Gerbi MEMM, Ponzi EAC, Ramalho LMP, Marques AMC, Carvalho $C M$, et al.. Infrared laser light further improves bone healing when associated with bone morphogenetic proteins and guided bone regeneration: an in vivo study in a rodent model. Photomed Laser Surg 2008;26:167-174.

13. Pinheiro ALB, Limeira Jr FA, Gerbi MEM, Ramalho LMP. Effect of $830 \mathrm{~nm}$ laser light on repair of bone defects grafted with organic bovine bone and decalcifield cortical osseous membrane. Journal of Clinical Laser Medicine and Surgery 2003;21:383-388.

14. Rochkid S, Kogan G, Luger E, Weiss J. Molecular structure of the bony tissue after experimental trauma to the mandibular region followed by laser therapy. Photomed Laser Surg 2004;22:249-253.

15. Dortbudak 0 , Haas R, Mailath-Pokony G. Effect of low power laser irradiation on bony implant sites. Clin Oral Implants Res 2002;13:288292.

16. Lopes, $C B$, Pinheiro AL, Da Silva NS, Salgado MA. Infrared laser photobiomodulation on bone tissue around dental implants: A Raman spectroscopy and scanning electronic microscopy study in rabbits. Photomed Laser Surg 2007;25:96-101.

17. Khaddra $\mathrm{M}$, Ronold $\mathrm{H}$, Lyngstadaas $\mathrm{S}$, Ellingsen J, Haanaes, H. Low level laser therapy stimulates bone-implant interaction: an experimental study in rabbits. Clin Oral Implants Res 2004;15:325-332.

18. Guzzardella G, Torricelli N, Giardino R. Osseointegration of endosseous ceramic implants after postoperative low power laser stimulation: an in vivo comparative study. Clin Oral Implants Res 2004;14:226-232.

19. Jakse N, Payer M, TangI S, Berghld A, Kirmeier R, Lorenzoni M. Influence of low level laser treatment on bone regeneration and osseointegration of dental implants following sinus augmentation: an experimental study on sheep. Clin Oral Implants Res 2007;18:517-524.

20. Weber JBB, Pinheiro ALB, De Oliveira MG, Oliveira FA, Ramalho LM. Laser therapy improves healing of bone defects submitted to autologous bone graft. Photomed Laser Surg 2006;24:38-44.

21. Torres CS, Santos JN, Monteiro JS, Amorim PG, Pinheiro ALB. Does the use of laser photobiomodulation, bone morphogenetic proteins, and guided bone regeneration improve the outcome of autologous bone grafts? An in vivo study in a rodent model. Photomed Laser Surg 2008; 26:371-377.

22. Lopes $C B$, Pinheiro AL, Duarte J, Martins MC. IR laser light reduces loading time of dental implants: A Raman spectroscopic study. Photomed Laser Surg 2005;23:27-31. 